\title{
Once Again: \\ The Financial Situation of the EPS
}

\section{Executive Committee proposes increase in unit fee}

We have already reported in Europhysics News on the development of the EPS with respect to its financial resources (see for example No. 8, March 1970). The situation has been, and remains, unsatisfactory. For 1969 about forty percent of the budget remained uncovered. A detailed account of the 1969 development and the outlook for 1970 follows below.

The reasons for the present deficit are well known :

(a) The growth of Individual Ordinary Membership has remained far below expectation; (b) the EPS does not possess working capital to bridge the gap between income and expenditure during the initial build-up of activities, yet these activities must be sustained if there is to be a development at all.

We recall that the guidelines for reaching a solvent situation have always been that one third of the budget should be covered by membership fees from National Societies and Academies, one third by membership fees from Individual Ordinary Members and one third by donations, gifts and Associate Membership fees. At present, this implies an income of the order of $100000 \mathrm{Sw}$. frs per year from each of the three categories. We are still far from this goal as regards Individual Ordinary Membership. The actual number of Individual Ordinary Members is about 840 , which number must increase by a factor of six if we are to secure sufficient income from this category.

By the time of the Paris meeting of Council (February 1970) it had become clear that it would be unrealistic to rely on a very steep increase in the number of Individual Ordinary Members for the near future (though it is gratifying to observe that there has been a considerable increase in membership since $\mathrm{Fe}$ bruary, thanks in particular to direct appeals by some of our National Societies to their members, urging them to become Individual Ordinary Members of the EPS). The development of Individual Ordinary Membership is presented graphically in the figure below.

Associate Membership is in steady development and we expect an income close to what has been projected for this category by the end of this year. In Paris, Council recommended that the National Societies take an active part in promoting Associate Membership of the EPS.

Also, following a recommendation adopted by Council in Paris, a number of National Societies have contributed to this year's funds through a prepayment of membership fees. This has helped to alleviate the pressure somewhat.

Yet, in spite of strenuous efforts by the Executive Committee and the Main Secretariat to reduce expenses to an absolute minimum, there is still a gap between income and expenditure. At the Paris meeting, the Executive Committee was charged with the task of preparing further steps to achieve a healthier financial situation. The Executive Committee analysed the problem again at its meeting in Geneva on 19 May.

On the one hand, the Executive Com-

Development of Individual Ordinary Membership

- Individual Ordinary Members categories $4 a$ and $4 c$ -. - Budget estimates for 1969 and 1970

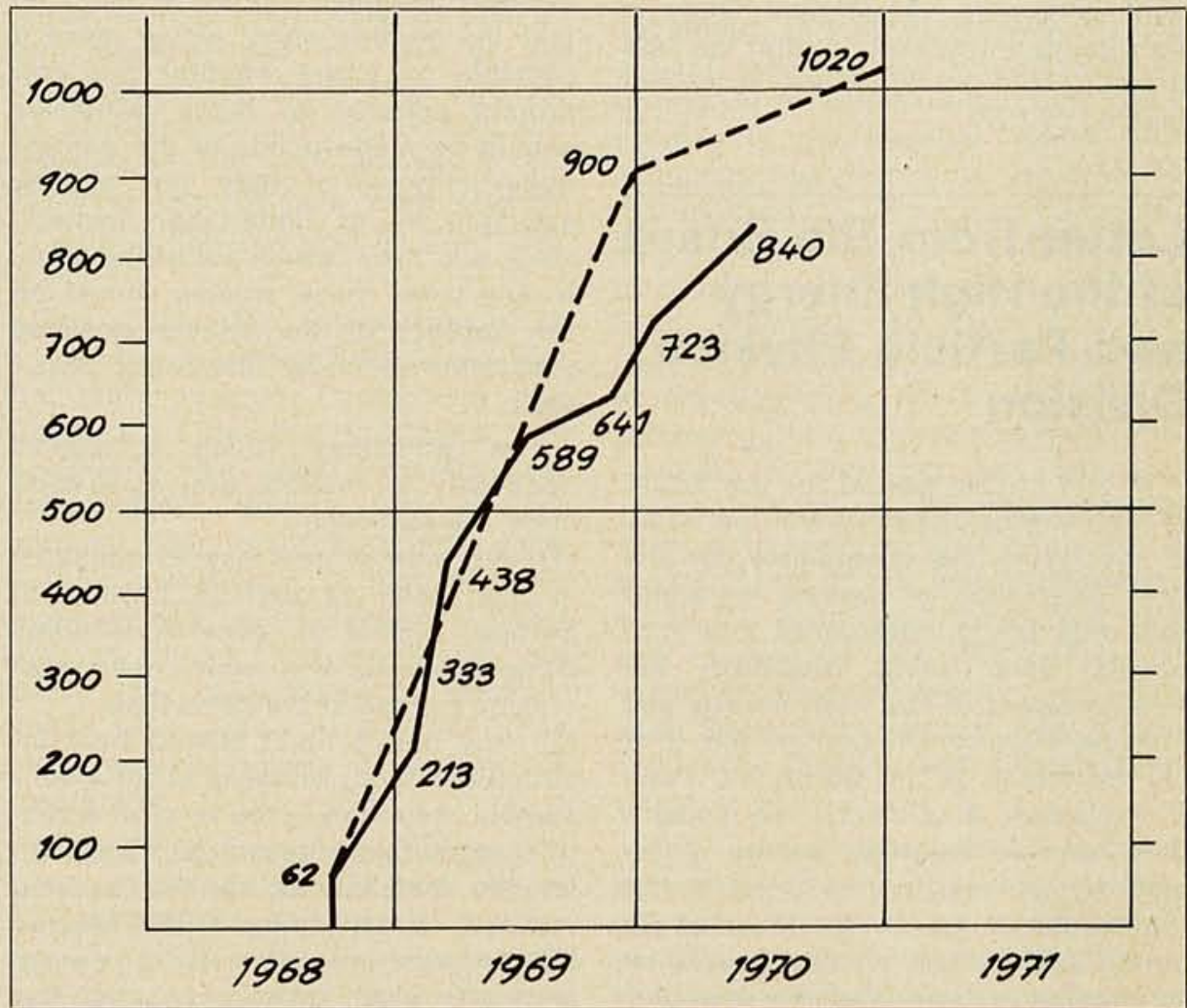


ratories category $4 \mathrm{~b}$ are determined according to a sliding-scale law (By-laws Rule 35). These rules were formulated some time ago: they were drafted by the Steering Committee during its meeting in London in May 1967 when a realistic appraisal of the funds required for the development of the future European Physical Society was not possible. Nevertheless, the rules provided a basis from which further planning could depart with the collaboration of a large number of National Societies and Academies.

In January 1968, at the meeting of the Steering Committee in Geneva, it became clear that the solvency of the Society, on the basis of the existing membership rules, could only be attained if the number of Individual Ordinary Members exceeded 5000. Now, three years after the London meeting, the Executive Committee judges that it must propose to the Council a doubling of the unit fee as of 1 January 1971. This will mean, if the Council accepts the proposal, that membership fees for all categories for 1971 will be based on a value of $9 \mathrm{Sw}$. frs as the unit fee. The number of unit fees due from the different categories of member is proposed to remain unchanged, with one exception : Individual Ordinary Members category $4 \mathrm{a}$ would pay 8 units at $9 \mathrm{Sw}$. frs instead of 16 units at $4.50 \mathrm{Sw}$. frs. In other words, membership fees for this category would remain unchanged at $72 \mathrm{Sw}$. frs per year.

The proposed new annual fees (as of 1 January 1971) are thus :

Individual Ordinary Members category $4 a: 72$ Sw. frs ;

Ordinary Members category 4b: same number of units as before (sliding scale, Rules 35b of By-laws) but now at $9 \mathrm{Sw}$. frs per unit :

Individual Ordinary Members category $4 c: 36$ Sw. frs.

In accordance with Rule 34 of the Bylaws, a letter has been sent by the President to all Ordinary Members on 1 June, announcing the proposed changes. Since the Members must have a period of at least six months to consider such proposals, a decision cannot be taken by Council before December 1970. The
INCOME

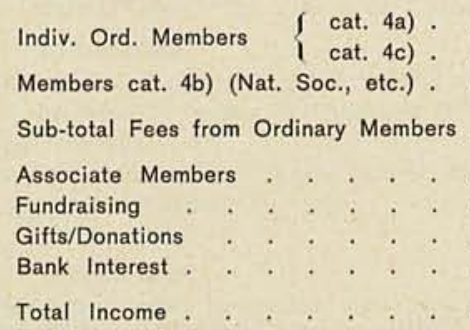

\section{EXPENDITURE *}

Meetings Executive Committee \& Council Advisory Committees

Divisions

General Correspondence, Accounting, Administration of all Membership Categories, EPS Booklets

Fundraising

Contingencies

\section{Europhysics News}

Travel/Living Expenses Committees

Florence Inaugural Conference

Total Expenditure

DEFICIT

\begin{tabular}{|r|r|}
\multicolumn{2}{|c|}{ Balance 1969} \\
\hline Budget & $\begin{array}{r}\text { Profit } \\
\text { and Loss }\end{array}$ \\
\hline 7200 & 3340 \\
12960 & 10466 \\
74900 & 87964 \\
95060 & 101770 \\
-- & 20000 \\
- & - \\
30000 & 21214 \\
340 & 260 \\
\hline 125400 & 143244 \\
\hline
\end{tabular}

Budget and Outlook

\begin{tabular}{|r|r|}
\hline \multicolumn{2}{|c|}{1970} \\
\hline Budget & Expected \\
\cline { 1 - 1 } 8640 & 6100 \\
16200 & 14400 \\
95000 & 89000 \\
119840 & 109500 \\
55000 & 30000 \\
30000 & - \\
28000 & 40000 \\
- & - \\
\hline 232840 & 179500 \\
\hline
\end{tabular}

\begin{tabular}{|r|r|r|r|}
\hline 50000 & 50000 \\
65000 & 60000 & 54000 & 54000 \\
10000 & 5000 & 78000 & 78000 \\
20000 & 20000 \\
95410 & 79097 & 106100 & 106100 \\
- & - & 12000 & - \\
2425 & - & 3000 & - \\
\hline 222835 & 194097 \\
20565 & 16983 \\
9000 & 3932 \\
- & 34119 \\
\hline 252400 & 249131 \\
\hline
\end{tabular}

* The EPS Secretariat staff at present consists of 6 persons. The above amounts comprise 65 to $75 \%$ of The cation-office equipment-charges-staff travel. Office space is offered free of charge by the Institut cation-office equipm
Battelle, Geneva.

1970 membership fees due from Members following Article 4b) of the Constitution

\begin{tabular}{|c|c|c|c|c|}
\hline & & $\begin{array}{l}\text { Number } \\
\text { of Society } \\
\text { Members } \\
\text { on 1.1.1970 }\end{array}$ & $\begin{array}{l}\text { Number } \\
\text { of Units } \\
\text { payable }\end{array}$ & $\begin{array}{l}\text { Amount of } \\
\text { fee to EPS } \\
\text { (Sw. frs) }\end{array}$ \\
\hline Ampère Group & Switzerland & 375 & 375 & 1687.50 \\
\hline Austrian Physical Society & Austria & 419 & 419 & 1885.50 \\
\hline Belgian Physical Society & Belgium & 230 & 230 & $1035 .-$ \\
\hline Bulgarian Academy of Sciences & Bulgaria & 102 & 102 & 459.- \\
\hline $\begin{array}{l}\text { Department of General Physics } \\
\text { and Astronomy of the USSR Academy } \\
\text { of Sciences }\end{array}$ & USSR & 2000 & 1450 & $6525 .-$ \\
\hline Eötvös Lorand Physical Society & Hungary & 525 & 517.50 & 2328.75 \\
\hline Finnish Physical Society & Finland & 604 & 572.80 & 2577.60 \\
\hline French Physical Society & France & 2400 & 1648.50 & 7418.25 \\
\hline German Physical Society & $\begin{array}{l}\text { Federal Rep. } \\
\text { Germany }\end{array}$ & 6400 & 3510 & $15795 .-$ \\
\hline $\begin{array}{l}\text { The Institute of Physics and } \\
\text { The Physical Society }\end{array}$ & UK & 14000 & 4950 & $22275 .-$ \\
\hline Institute "Ruder Boskovic" & Yugoslavia & 60 & 60 & 270.- \\
\hline Israel Physical Society & Israel & 197 & 197 & 886.50 \\
\hline Italian Physical Society & Italy & 1173 & 953.80 & 4292.10 \\
\hline The Netherlands' Physical Society & Netherlands & 2157 & 1528.50 & 6878.25 \\
\hline Norwegian Physical Society & Norway & 507 & 504.90 & 2272.05 \\
\hline $\begin{array}{l}\text { Physical Section, Union of Czechoslovak } \\
\text { Mathematicians and Physicists }\end{array}$ & Czechoslovakia & 380 & 380 & 1710.- \\
\hline $\begin{array}{l}\text { Physical Section of the Yugoslav } \\
\text { Association of Mathematicians, } \\
\text { Physicists and Astronomers }\end{array}$ & Yugoslavia & $200^{*}$ & $200^{*}$ & 900.- \\
\hline Portuguese Physics and Chemistry Society & Portugal & 200 & 200 & 900.- \\
\hline $\begin{array}{l}\text { Rumanian National Committee for } \\
\text { Pure and Applied Physics }\end{array}$ & Rumania & 300 & 300 & $1350 .-$ \\
\hline Royal Irish Academy & Ireland & 64 & 64 & 288.- \\
\hline Spanish Royal Society of Physics and Chemistry & Spain & $200^{*}$ & $200^{\star}$ & 900. - \\
\hline Swedish Physical Society & Sweden & $500^{*}$ & $500^{\star}$ & 2250. - $^{*}$ \\
\hline Swiss Physical Society & Switzerland & 860 & 752 & $3384,-$ \\
\hline Turkish Physical Society & Turkey & 160 & 160 & 720.- \\
\hline 1970 Total & & & & 88987.50 \\
\hline
\end{tabular}

* Figures not yet confirmed. 